\title{
Breast Self-Examination Practice Among Female Secondary School Students In Osogbo, Western Nigeria
}

\author{
I.N. Usman, S.O. Olanrewaju, and S.O. Usman
}

\begin{abstract}
BACKGROUND: Breast cancer is the most common invasive cancer affecting women worldwide. It comprises $22.9 \%$ of invasive cancers in women and $16 \%$ of all female cancers. It affects about $12 \%$ of the women population worldwide. In Nigeria, about one breast cancer death is reported in every 25 cases identified and the practice of breast self-examination has been reported to range from $19 \%$ to $43.2 \%$. This cross sectional study assessed the knowledge, attitude and practice of breast self-examination (BSE) among female secondary school students in Osogbo Metropolis. METHODS: A total of 400 respondents were selected using multistage sampling technique. Data were collected using pretested self-administered semi structured questionnaire, analyzed using Statistical Package for Social Sciences and presented using appropriate tables and charts. Level of significance set at $<\mathbf{0 . 0 5}$. RESULTS: The mean age \pm SD is $14.77 \pm 1.46$ years. $390(97.5 \%)$ respondents reported that they have heard of breast cancer while $235(58.8 \%)$ respondents stated that they have heard of breast self-examination (BSE). 15 $(3.8 \%)$ respondents said the procedures is time wasting while $82(20.5 \%)$ respondents said the procedures were strenuous. $199(49.8 \%)$ strongly disagree that performing breast selfexamination may expose them to breast cancer. Individuals with poor knowledge are one time less likely to do breast selfexamination $(\mathrm{OR}=1.245, \mathrm{CI}=0.647-2.394)$ while in terms of attitude, those with unfavorable attitude are one time less likely to do breast self-examination $(\mathrm{OR}=1.025 \mathrm{CI}=\mathbf{0 . 9 4 9}-1.107)$. CONCLUSION: This study revealed a larger proportion of respondents have heard about breast cancer and breast selfexamination but with inadequate knowledge of the correct procedures of breast self-examination (BSE) thereby resulting into poor attitude $\&$ practice of breast self-examination (BSE). This challenge therefore indicates an urgent need for continuous awareness and sensitization programs in the communities.
\end{abstract}

Keywords — Knowledge, Attitude, Practice, Breast.

\section{INTRODUCTION}

Breast cancer is an uncontrolled growth of abnormal cells in the milk producing glands of the breast or in the ducts that deliver milk to the nipples. Breast cancer is the most common invasive cancer affecting women worldwide. It comprises $22.9 \%$ of invasive cancers in women and $16 \%$ of all female cancers [1]. It affects about $12 \%$ of the women population worldwide [2]. Report on the incidence of breast cancer reveals that one out of every eight women in the world stands a chance of having the disease in her life time [3]. In the developing countries, the rate of breast cancer is reportedly higher than developed countries [4]. Approximately half of the breast cancer cases and $60 \%$ of the deaths are estimated to take place in developing countries [5]. The high incidence of breast cancer necessitates the need for early detection which enhances early initiation of treatment thereby reducing mortality. The various diagnostic measures for early detection of breast cancer include breast self-examination (BSE), clinical breast examination (CBE) and mammography [6].

Breast self-examination (BSE) is a screening method that people perform the procedures on their own in an attempt to detect early breast cancer. Breast self-examination is easy to perform and cheap but despite these the rate of practice of breast self-examination is low and varies in different countries. Studies have cited the reasons for the low practice of breast self-examination which is as a result of inadequate knowledge of breast self-examination, lack of time, lack of self-confidence in their ability to perform the technique correctly, fear of possible discovery of a lump, and embarrassment associated with handling of the breast [7]. Breast self-examination is often carried out once in a month, between the $7^{\text {th }}$ and $10^{\text {th }}$ day of the menstrual cycle, to detect breast cancer at the early stages of growth thereby ensuring a better prognosis when treated [8]. The method involves the woman herself looking at and feeling each breast for possible development of lumps, discharge other than breast milk, swelling of the breast, skin irritation or dimpling, nipple abnormalities (such as pain, redness, scaliness, or turning inward).In Nigeria, the practice of breast self-examination has been reported to range from $19 \%$ to $43.2 \%$ [9].

A study of BSE done among female students of the University of Ibadan, Ibadan reported that $82.5 \%$ of students have heard of BSE, $53.2 \%$ of them knew what BSE is used for while only $25 \%$ practice BSE regularly and $30 \%$ practice BSE infrequently [10]. A research on the knowledge, attitude and practice of respondents about breast self-examination among female secondary school teacher in a rural community in Oyo State showed that $54 \%$ of the respondent had poor knowledge, $48 \%$ had poor attitude and $62 \%$ demonstrated a poor practice [11].

In a study done by Yakubu and others on knowledge, attitude, and practice of breast self-examination among female nurses in Aminu Kano teaching hospital, Kano, Nigeria stated that $100 \%$ respondents unanimously agree that BSE is useful and $84.3 \%$ of the respondents responded that they can encourage BSE to others [12]. Sani et al stated in their research on influence of educational level on knowledge and practice of breast self-examination among

Published on March 14, 2020

I.N. Usman, Ladoke Akintola University of Technology, Osogbo, Nigeria.

S.O. Olanrewaju, University of Osun, Osogbo, Nigeria.

S.O. Usman, Nnamdi Azikiwe University, Nnewi, Nigeria

(e-mail: senatorhopsy@yahoo.com) 
women in Sokoto, Nigeria that $65 \%$ of the respondents practiced BSE while $35 \%$ did not practice BSE and among the $65 \%$ of the respondents that practiced BSE, only $52.7 \%$ practiced BSE monthly [13]. A research done on Knowledge, attitude and practice of breast self-examination among female undergraduate students in the University of Buea stated that $41 \%$ of the respondents in the study had ever performed BSE, 29.5\% have performed BSE within the past 12 months. Only 3\% had performed BSE regularly (10-12 times) within the past 12 months [14].

\section{SPECIFIC OBJECTIVES}

- To determine the knowledge of breast selfexamination (BSE) among female secondary school students in Osogbo Metropolis.

- To evaluate the attitude of breast self-examination (BSE) among female secondary school students in Osogbo Metropolis.

- To assess the practice of breast self-examination (BSE) among female secondary school students in Osogbo Metropolis.

\section{METHODS}

This descriptive cross-sectional survey was carried out in Osogbo Metropolis, the capital of Osun state, South-West Nigeria. The study population consists of female secondary school students in selected secondary schools.

A semi-structured questionnaire was used to seek information about the socio-demographic characteristics of the female students, knowledge, attitude and practices of breast self-examination by female secondary school students on breast self-examination. Ethical approval to carry out the study was obtained from the ethical review committee of Ministry of Health, Abeere, Osun State. A multi-stage sampling technique was used to select the adolescent girls from the selected schools in Osogbo metropolis.

\section{Sample Size Estimation}

Sample size calculation was done using Leslie Fischer's formula, for population $>10,000$ with a $5 \%$ or 0.05 degree of precision and $95 \%$ confidence interval. There seems to be no data available as regards the proportion of female secondary school students practicing breast self-examination in Osogbo Metropolis, but a study on Breast self-examination practice among female senior secondary school students in Abuja, reported $34.6 \%$ (15). The Leslie Fischer's formula for sample size when population is $>10,000$ is:

\section{$\mathbf{n}=\mathbf{Z}^{2} \mathbf{P Q} / \mathbf{d}^{2}$}

Where:

$\mathrm{n}=$ minimum sample size,

$\mathrm{Z}=$ standard normal deviation at $95 \%$ confidence interval which is 1.96 ,

$\mathrm{d}=$ degree of precision or error margin which is $5 \%$ (taken

$\mathrm{P}=$ proportion of the target population from previous studies (estimated at $34.6 \%$ which is $34.6 / 100=0.35$ ),

$\mathrm{Q}=$ alternate proportion $(1-\mathrm{P})$ which is $1-0.346=0.65$

$\mathrm{n}=\underline{(1.96)^{2}(0.35)(0.65)}=349$ $(0.05)^{2}$

Adding a $5 \%$ attrition rate, the minimum sample size $(\mathrm{n})=$ $5 / 100 \times 349=17$
Therefore, minimum sample size (n) is $349+17=366$.

\section{STATISTICAL ANALYSIS}

Data was statistically analyzed using Statistical Package for Social Sciences (SPSS) version 23.0 software. All data were expressed as Mean \pm Standard Deviation (SD). Statistical test of significance were performed by Chi- Square test. Level of significance was set with p-value less than 0.05 .

\section{RESULTS}

\section{SOCIO-DEMOGRAPHIC DATA}

400 respondents participated in the study and the mean age \pm SD is $14.77 \pm 1.46$. Based on the level of education of respondents, $84(21.0 \%)$ are in SSS1, $105(26.3 \%)$ are in SSS2 while 211(52.8\%) are in SSS3. In term of the type of school of the respondents $349(87.3 \%)$ are from private schools while $51(12.8 \%)$ are from public school. Age category of the respondents shows that $300(75.1 \%)$ are between 13-15 years, 93 (23.4\%) are between 16-18years, and $7(1.8 \%)$ are 19 above. As regards the position of the respondents in their family, $143(35.8 \%)$ reported that they were first born, 106 (26.5\%) were second born 83 (20.8\%) were third born, $53(13.3 \%)$ were last born of their family while $15(3.8 \%)$ respondents chose others.

\section{SOCIO-DEMOGRAPHIC \& TREATMENT DATA}

\begin{tabular}{|c|c|c|}
\hline Variables & Frequency & $\begin{array}{l}\text { Percentage } \\
(\%)\end{array}$ \\
\hline \multicolumn{3}{|l|}{ Ethnicity of respondents } \\
\hline Yoruba & 390 & 97.5 \\
\hline Igbo & 9 & 2.3 \\
\hline Hausa & 1 & 0.3 \\
\hline Total & 400 & 100.0 \\
\hline \multicolumn{3}{|l|}{ Religion of respondents } \\
\hline Christianity & 228 & 57.0 \\
\hline Islam & 172 & 43.0 \\
\hline Total & 400 & 100.0 \\
\hline \multicolumn{3}{|c|}{ Level of education of respondents } \\
\hline SSS1 & 84 & 21.0 \\
\hline SSS2 & 105 & 26.3 \\
\hline SSS3 & 211 & 52.8 \\
\hline Total & 400 & 100.0 \\
\hline \multicolumn{3}{|l|}{ Type of school } \\
\hline Private & 349 & 87.3 \\
\hline Public & 51 & 12.8 \\
\hline Total & 400 & 100.0 \\
\hline \multicolumn{3}{|l|}{ Age in categories } \\
\hline 13- 15 years & 300 & 75.1 \\
\hline $16-18$ years & 93 & 23.4 \\
\hline 19 and above & 7 & 1.8 \\
\hline Total & 400 & 100.0 \\
\hline \multicolumn{3}{|l|}{ Family setting } \\
\hline Monogamous & 346 & 86.5 \\
\hline Polygamous & 54 & 13.5 \\
\hline Total & 400 & 100.0 \\
\hline Mother level of education & & \\
\hline
\end{tabular}




\begin{tabular}{|l|l|l|} 
No formal education & 13 & 3.3 \\
\hline Primary & 50 & 12.5 \\
\hline Secondary & 235 & 58.8 \\
\hline Tertiary & 102 & 25.5 \\
\hline Total & 400 & 100.0 \\
\hline Father level of education & & \\
\hline No formal education & 12 & 3.0 \\
\hline Primary & 26 & 6.5 \\
\hline Secondary & 232 & 58.0 \\
\hline Tertiary & 130 & 32.5 \\
\hline Total & 400 & 100.0 \\
\hline Position in the family & & \\
\hline First & 143 & 35.8 \\
\hline Second & 106 & 26.5 \\
\hline Third & 83 & 20.5 \\
\hline Last & 53 & 20.8 \\
\hline Others & & 100.0 \\
\hline
\end{tabular}

\begin{tabular}{|l|l|l|} 
Higher levels of hormones & 17 & 4.3 \\
\hline Alcohol Consumption & 11 & 2.8 \\
\hline Radiation exposure & 6 & 1.5 \\
\hline All of the above & 35 & 8.8 \\
\hline No idea & 190 & 47.6 \\
\hline Total & 400 & 100.0 \\
\hline
\end{tabular}

KNOWLEDGE ABOUT BREAST SELF-EXAMINATION PROCEDURE $(\mathrm{N}=400)$

\begin{tabular}{|l|l|l|}
\hline Variable & Frequency & $\begin{array}{l}\text { Percentage } \\
\text { (\%) }\end{array}$ \\
\hline $\begin{array}{l}\text { Have you heard of breast self- } \\
\text { examination? }\end{array}$ & 235 & 58.8 \\
\hline Yes & 165 & 41.3 \\
\hline No & 400 & 100.0 \\
\hline Total & 116 & 71.0 \\
\hline $\begin{array}{l}\text { Gender that should routinely } \\
\text { perform breast self-examination } \\
\text { (BSE) }\end{array}$ & 400 & 29.0 \\
\hline $\begin{array}{l}\text { Female (Correct answer) } \\
\text { Male, Both male and female } \\
\text { (Incorrect answer) }\end{array}$ & 284 & 100.0 \\
\hline $\begin{array}{l}\text { Total } \\
\text { Age that breast self-examination } \\
\text { (BSE)should begin }\end{array}$ & 382 & 78.5 \\
\hline 8 -15years (correct) & 18 & 21.5 \\
\hline 16 years and above (Incorrect) & 400 & 100.0 \\
\hline \begin{tabular}{l} 
Total \\
\hline
\end{tabular} & 16 \\
\hline
\end{tabular}

KNOWLEDGE ABOUT BREAST CANCER DISEASE ( $\mathrm{N}=400)$

\begin{tabular}{|c|c|c|}
\hline Variable & Frequency & $\begin{array}{l}\text { Percentage } \\
(\%)\end{array}$ \\
\hline \multicolumn{3}{|l|}{$\begin{array}{l}\text { Have you ever heard of breast } \\
\text { cancer disease }\end{array}$} \\
\hline Yes & 390 & 97.5 \\
\hline No & 10 & 2.5 \\
\hline Total & 400 & 100.0 \\
\hline \multicolumn{3}{|l|}{$\begin{array}{l}\text { Can breast cancer develop from } \\
\text { the breast tissue }\end{array}$} \\
\hline Yes & 336 & 84.0 \\
\hline No & 64 & 16.0 \\
\hline Total & 400 & 100.0 \\
\hline \multicolumn{3}{|l|}{ Symptoms of breast cancer disease } \\
\hline Breast lump & 92 & 23.0 \\
\hline $\begin{array}{l}\text { Constant pain in part of the breast/ } \\
\text { Armpit }\end{array}$ & 67 & 16.8 \\
\hline $\begin{array}{l}\text { Nipple Changing position/ shape or } \\
\text { becoming inverted }\end{array}$ & 3 & 0.8 \\
\hline One breast becoming larger or lower & 9 & 2.3 \\
\hline Rash on/ around nipple & 7 & 1.8 \\
\hline $\begin{array}{l}\text { Thickening different from the other } \\
\text { breast tissue }\end{array}$ & 6 & 1.5 \\
\hline All of the above & 79 & 19.8 \\
\hline No idea & 137 & 34.3 \\
\hline Total & 400 & 100.0 \\
\hline \multicolumn{3}{|l|}{$\begin{array}{l}\text { Risk factors for breast cancer } \\
\text { disease }\end{array}$} \\
\hline Age & 8 & 2.0 \\
\hline Obesity & 20 & 5.0 \\
\hline Biological sex & 12 & 3.0 \\
\hline Diet & 5 & 1.3 \\
\hline Lack of child bearing & 5 & 1.3 \\
\hline Lack of breast feeding & 24 & 6.0 \\
\hline Genetics & 22 & 5.5 \\
\hline
\end{tabular}

KNOWLEDGE ABOUT BREAST SELF-EXAMINATION PROCEDURE $(\mathrm{N}=400)$

\begin{tabular}{|l|l|l|}
\hline Variable & Frequency & $\begin{array}{l}\text { Percentage } \\
(\%)\end{array}$ \\
\hline $\begin{array}{l}\text { How often breast self-examination } \\
\text { (BSE) should be done }\end{array}$ & 142 & 35.5 \\
\hline Monthly (Correct answer) & 258 & 64.5 \\
\hline Other responses (Incorrect answer) & 400 & 100.0 \\
\hline Total procedure for breast & & \\
\hline $\begin{array}{l}\text { Palpating pelf-examination (BSE) } \\
\text { Palpate with palm and minimum of } \\
\text { three fingers (Correct answer) }\end{array}$ & 94 & 23.5 \\
\hline Other responses(Incorrect answer) & 306 & 76.5 \\
\hline Total & 400 & 100.0 \\
\hline
\end{tabular}

Figure 1: Summarized Knowledge On Breast Self-Examination

Out of 400 respondents, $128(32.0 \%)$ have adequate knowledge on breast self-examination while $272(68.0 \%)$ have inadequate knowledge on breast self-examination as represented in figure 1 below. 


\section{PIE CHART SHOWING BREAST SELF EXAMINATION KNOWLEDGE LEVEL}

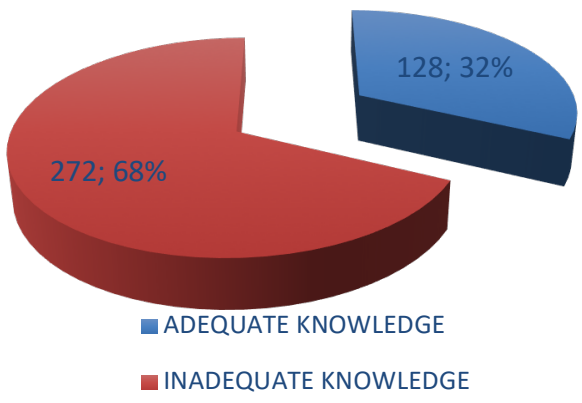

ATTITUDE TOWARDS BREAST SELF-EXAMINATION

Attitude towards breast self-examination $(n=400)$

\begin{tabular}{|c|c|}
\hline Variable & $\begin{array}{l}\text { Frequency } \\
(\%)\end{array}$ \\
\hline \multicolumn{2}{|l|}{$\begin{array}{l}\text { Breast self-examination is necessary for early } \\
\text { detection of breast cancer }\end{array}$} \\
\hline Strongly agree & $259(64.8)$ \\
\hline Agree & $132(33)$ \\
\hline Unsure & $7(1.8)$ \\
\hline Disagree & $1(0.3)$ \\
\hline Strongly disagree & $1(0.3)$ \\
\hline Total & $400(100.0)$ \\
\hline \multicolumn{2}{|l|}{\begin{tabular}{|lcll}
$\begin{array}{l}\text { Breast } \\
\text { mandatory for all females }\end{array}$ & should be & made \\
\end{tabular}} \\
\hline Strongly agree & $225(56.3)$ \\
\hline Agree & $140(35.0)$ \\
\hline Unsure & $17(4.3)$ \\
\hline Disagree & $14(3.5)$ \\
\hline Strongly disagree & $4(1.0)$ \\
\hline Total & $400(100.0)$ \\
\hline \multicolumn{2}{|l|}{$\begin{array}{l}\text { Performing breast self-examination may expose } \\
\text { me to breast cancer }\end{array}$} \\
\hline Strongly agree & $14(3.5)$ \\
\hline Agree & $20(5.0)$ \\
\hline Unsure & $36(9.0)$ \\
\hline Disagree & $131(32.8)$ \\
\hline Strongly disagree & $198(49.5)$ \\
\hline Total & $400(100.0)$ \\
\hline \multicolumn{2}{|l|}{$\begin{array}{l}\begin{array}{l}\text { Breast self-examination } \\
\text { religious/cultural belief }\end{array} \\
\text { is }\end{array}$} \\
\hline Strongly agree & $7(1.8)$ \\
\hline Agree & $12(3.0)$ \\
\hline Unsure & $23(5.8)$ \\
\hline Disagree & $132(33.0)$ \\
\hline Strongly disagree & $226(56.5)$ \\
\hline Total & $400(100.0)$ \\
\hline \multicolumn{2}{|l|}{$\begin{array}{l}\text { Breast self-examination is a waste of time and } \\
\text { resources }\end{array}$} \\
\hline Strongly agree & $61(16.2)$ \\
\hline Agree & $43(11.4)$ \\
\hline
\end{tabular}

\begin{tabular}{|l|l|} 
Unsure & $91(24.2)$ \\
\hline Disagree & $134(33.5)$ \\
\hline Strongly disagree & $239(59.8)$ \\
\hline Total & $400(100.0)$ \\
\hline $\begin{array}{l}\text { Early detection of breast cancer with breast self- } \\
\text { examination can save the life of a woman }\end{array}$ & \\
\hline Strongly agree & $261(65.3)$ \\
\hline Agree & $119(29.8)$ \\
\hline Unsure & $11(2.8)$ \\
\hline Disagree & $9(2.3)$ \\
\hline Strongly disagree & $0(0.0)$ \\
\hline Total & $400(100.0)$ \\
\hline
\end{tabular}

Figure 2: Summarized Attitude Towards Breast Self-Examination

The pie chart below shows the respondents attitude towards breast selfexamination in this study. Out of the 400 respondents, $366(91 \%)$ have a favourable attitude towards breast self-examination while $34(9 \%)$ have an unfavourable attitude towards breast self-examination.

\section{PIE CHART SHOWING ATTITUDE TO BREAST SELF EXAMINATION}

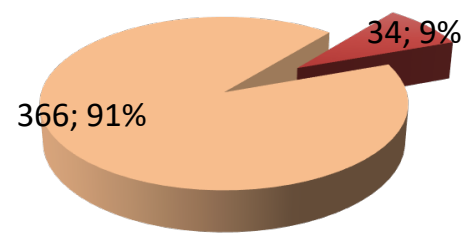

FAVOURABLE ATTITUDE — UNFAVOURABLE ATTITUDE

PRACTICE OF BREAST SELF EXAMINATION (BSE)

Practice of breast self-examination (BSE) $(\mathrm{n}=400)$

\begin{tabular}{|l|l|}
\hline Variable & $\begin{array}{l}\text { Frequency } \\
\text { (\%) }\end{array}$ \\
\hline Ever performed breast self-examination & \\
\hline Yes & $109(27.3)$ \\
\hline No & $291(72.8)$ \\
\hline Total & $400(100.0)$ \\
\hline $\begin{array}{l}\text { Performed breast self-examination in the past } \\
\text { six months }\end{array}$ & \\
\hline Yes & $78(19.5)$ \\
\hline No & $322(80.5)$ \\
\hline Total & $400(100.0)$ \\
\hline $\begin{array}{l}\text { If yes what are the reasons why breast self- } \\
\text { examination was performed in the past six } \\
\text { months (N=78) }\end{array}$ & \\
\hline $\begin{array}{l}\text { To examine my breast regularly to prevent breast } \\
\text { cancer }\end{array}$ & $47(60.3)$ \\
\hline Because breast cancer is in my family history & $4(5.1)$ \\
\hline I just feel like doing it & $27(34.6)$ \\
\hline Total & $78(100.0)$ \\
\hline $\begin{array}{l}\text { If no what are the reasons why breast self- } \\
\text { examination was not performed in the past six } \\
\text { months (N=322) }\end{array}$ \\
\hline I do not have time for it & $26(8.1)$ \\
\hline I don't have any symptoms of breast cancer & $49(15.2)$ \\
\hline I don't know how to do it & $167(51.9)$ \\
\hline
\end{tabular}




\begin{tabular}{|l|l|} 
I don't think it is necessary & $20(6.2)$ \\
\hline I feel shy & $6(1.9)$ \\
\hline I'm healthy & $36(11.2)$ \\
\hline I'm scared of being diagnosed with breast cancer & $8(2.5)$ \\
\hline It may be painful & $10(3.1)$ \\
\hline Total & $322(100.0)$ \\
\hline
\end{tabular}

PRACTICE OF BREAST SELF EXAMINATION (BSE)

\begin{tabular}{|c|c|}
\hline Variable & $\begin{array}{l}\text { Frequency } \\
(\%)\end{array}$ \\
\hline \multicolumn{2}{|l|}{$\begin{array}{l}\text { Age you started performing breast self- } \\
\text { examination (109) }\end{array}$} \\
\hline 8.0 & $1(0.9)$ \\
\hline 10.0 & $6(5.5)$ \\
\hline 11.0 & $2(1.8)$ \\
\hline 12.0 & $35(32.1)$ \\
\hline 13.0 & $24(22.0)$ \\
\hline 14.0 & $18(16.5)$ \\
\hline 15.0 & $11(10.1)$ \\
\hline 16.0 & $5(4.6)$ \\
\hline 17.0 & $4(3.7)$ \\
\hline 18.0 & $3(2.8)$ \\
\hline Total & $109(100.0)$ \\
\hline \multicolumn{2}{|l|}{$\begin{array}{l}\text { Last time you performed breast self- } \\
\text { examination }(\mathrm{N}=109)\end{array}$} \\
\hline Between 3 to 6 months ago & $21(19.3)$ \\
\hline Between $6 \&$ a year ago & $17(15.6)$ \\
\hline Less than a month ago & $59(54.1)$ \\
\hline More than a year & $12(11.0)$ \\
\hline Total & $109(100.0)$ \\
\hline \multicolumn{2}{|l|}{$\begin{array}{l}\text { Period of menstrual cycle breast was examined } \\
(\mathrm{N}=109)\end{array}$} \\
\hline After Menstruation & $42(38.5)$ \\
\hline Before Menstruation & $20(18.3)$ \\
\hline During Menstruation & $10(9.2)$ \\
\hline No particular time & $37(33.9)$ \\
\hline Total & $109(100.0)$ \\
\hline \multicolumn{2}{|l|}{$\begin{array}{l}\text { How often you perform breast self-examination } \\
\text { in a year }(\mathrm{N}=109)\end{array}$} \\
\hline Anytime & $21(19.3)$ \\
\hline Daily & $33(30.3)$ \\
\hline Weekly & $19(17.4)$ \\
\hline Monthly & $29(26.6)$ \\
\hline Yearly & $7(6.4)$ \\
\hline Total & $109(100.0)$ \\
\hline \multicolumn{2}{|l|}{$\begin{array}{l}\text { Methods of breast self-examination often } \\
\text { practiced }(\mathrm{N}=109)\end{array}$} \\
\hline During shower & 33 \\
\hline On the bed lying down & 18 \\
\hline Standing in front of the mirror & 54 \\
\hline All of the above & 4 \\
\hline Total & $109(100.0)$ \\
\hline
\end{tabular}

\section{PRACTICE OF BREAST SELF EXAMINATION (BSE)}

\begin{tabular}{|l|l|} 
Variable & Frequency (\%) \\
\hline $\begin{array}{l}\text { Steps } \\
\text { of breast self-examination followed in front } \\
\text { of the mirror } \mathbf{( N = 5 8 )}\end{array}$ & \\
\hline $\begin{array}{l}\text { Place hand on hip, press down \& make the chest } \\
\text { muscle tense }\end{array}$ & $6(10.3)$ \\
\hline
\end{tabular}

\begin{tabular}{|c|c|}
\hline Raise the arm above/ behind the head & $21(36.2)$ \\
\hline Squeeze each nipple gently for any discharge & $22(37.9)$ \\
\hline Start with arms at sides & $7(12.1)$ \\
\hline All of the above & $2(3.4)$ \\
\hline Total & $58(100.0)$ \\
\hline \multicolumn{2}{|l|}{$\begin{array}{l}\text { Steps of breast self-examination followed } \\
\text { during shower }(\mathrm{N}=37)\end{array}$} \\
\hline Start by raising an arm behind your head & $10(27.0)$ \\
\hline Use the pad of the hand to examine the breast & $12(32.4)$ \\
\hline $\begin{array}{l}\text { Use soapy hand to press firmly on the breast } \\
\text { against the chest wall }\end{array}$ & $8(21.6)$ \\
\hline All of the above & $7(18.9)$ \\
\hline Total & $37(100.0)$ \\
\hline \multicolumn{2}{|l|}{$\begin{array}{l}\text { Steps of breast self-examination followed on } \\
\text { bed while lying down }(\mathrm{N}=22)\end{array}$} \\
\hline Lie down on the back $\&$ be comfortable & $7(31.8)$ \\
\hline $\begin{array}{l}\text { Place a pillow under the shoulder of the side to } \\
\text { be examined }\end{array}$ & $3(13.6)$ \\
\hline Use the lip of the hand to examine the breast & $8(36.4)$ \\
\hline All of the above & $4(18.2)$ \\
\hline Total & $22(100.0)$ \\
\hline
\end{tabular}

Figure 3: Summarized Practice On Breast Self-Examination

The pie chart below shows the respondents practice of breast selfexamination in this study. Out of the 400 respondents, $44(11 \%)$ have good practice of breast self-examination while $356(89 \%)$ have poor practice of breast self-examination.

\section{PIE CHART SHOWING PRACTICE OF BREAST SELF EXAMINATION}

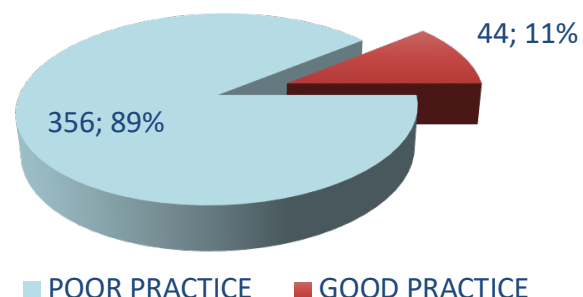

POOR PRACTICE — GOOD PRACTICE

\section{PREDICTORS OF PRACTICE OF BREAST SELF-EXAMINATION}

According to the table below, individuals with poor knowledge are one time less likely to do breast self-examination $(\mathrm{P}<0.05$, OR $=1.245, \mathrm{CI}=0.647$ 2.394) while in terms of attitude, those with unfavourable attitude are one time less likely to do breast self-examination. $(\mathrm{P}<0.05, \mathrm{OR}=1.025 \mathrm{CI}=$ $0.949-1.107)$.

\begin{tabular}{|c|c|c|c|c|}
\hline \multirow[b]{2}{*}{ Variable } & \multirow[b]{2}{*}{$\begin{array}{l}\text { Statistical } \\
\text { significance }\end{array}$} & \multirow[b]{2}{*}{$\begin{array}{l}\text { Odds } \\
\text { ratio }\end{array}$} & \multicolumn{2}{|c|}{$\begin{array}{l}\text { Confidence } \\
\text { interval }\end{array}$} \\
\hline & & & $\begin{array}{l}\text { Lower } \\
\text { level }\end{array}$ & $\begin{array}{l}\text { Upper } \\
\text { level }\end{array}$ \\
\hline \multicolumn{5}{|l|}{$\begin{array}{l}\text { Good knowledge } \\
\text { with reference to }\end{array}$} \\
\hline Poor knowledge & 0.511 & 1.245 & 0.647 & 2.394 \\
\hline $\begin{array}{l}\text { Favourable } \\
\text { attitude } \\
\text { with reference to }\end{array}$ & 0.963 & 1.025 & 0.949 & 1.107 \\
\hline
\end{tabular}

\section{DISCUSSION}

This research outcome has shown that $58.8 \%$ of the respondents have heard about breast self-examination (BSE) 
and $27.3 \%$ of the respondents have ever performed BSE while only $19.5 \%$ of the respondents performed BSE in the past six months. This is similar to a previous study reported in Abuja that $56.4 \%$ of the respondents knew about BSE and $10.1 \%$ of the respondents have ever performed BSE [15] but it is in contrast to Assuit, South Egypt study that revealed that $87.9 \%$ of the respondents reported to have heard about Breast Self-Examination (BSE) [16]. Related to this is a study done at University of Ibadan, Nigeria which described that $82.5 \%$ have heard of BSE and only $11 \%$ female individuals practice the procedure regularly (10).

It was observed in this study that having heard about BSE does not necessarily imply to high performance rate of breast self-examination (BSE). The poor practice of BSE among the respondents in this study was because they do not know how to perform the procedure and perhaps they appear not to also know the specific period to perform breast selfexamination. However, $84.3 \%$ of the respondents stated that they would like to know more about breast self-examination (BSE) and its procedure, which implies that young adolescent girls are eager to learn more about breast selfexamination (BSE) which will enhance positive attitude and behaviour towards the practice of breast self-examination (BSE) at an early stage of life.

Findings of this study indicated that $27.3 \%$ of the respondents practiced BSE, but only $19.5 \%$ performed breast self-examination in the past six months. This illustrated that a very low percentage of the female secondary school students were really practicing BSE. In disparity to this study, there is high level of practice of BSE among women of about $65.3 \%$ in a research done at Sokoto Nigeria (13).

The peak proportion of the respondents obtained their first information from their school whereas the least source of information on BSE was obtained from the church. Contrast observations about the respondents' first information were stated in a research held among female secondary school teachers in Ilorin, Nigeria where $29.9 \%$ of those studied indicated that the information were obtained from the television, This may be as a result of insufficient health education by health workers to females on BSE (8).

Furthermore, only $19.5 \%$ respondents were aware that the correct period of menstrual cycle for breast selfexamination was after menstruation while $13.0 \%$ respondents examined their breasts at any time they felt like. This does not agree with a previous research outcome on breast self-examination among female undergraduates in Enugu which revealed that $62 \%$ respondents declared that they examined their breasts after menstruation while $54.6 \%$ examine their breasts at any time they felt like [17]. The poor knowledge on the methods and timing of breast selfexamination might be because the respondents were not taught the procedures of BSE as this does not necessarily fall into the syllabus of any of the main courses the respondents or in other cases, little attention paid to such topics by school instructors because this area of study in general is not taken as seriously as one would expect.

The educational status has significant effect on knowledge on BSE in which the respondents' level of education may determine their knowledge on BSE. .This was in agreement to a BSE study among women in Sokoto Nigeria in which there was significant relationship between the educational level and the knowledge of BSE among those respondents (13). Respondents in the higher level of education were older in age and possibly taught the procedure of BSE (who to routinely perform BSE, age to start BSE, how often BSE have to be done, procedures for BSE, signs and risk factors of BSE, among others) by their teachers. This is similar to a previous study done among female secondary school students in which the higher level of education determines the knowledge on BSE [15].

The age of the respondents is significantly associated with the practice of BSE which is likely due to the fact that respondents with adequate knowledge on BSE will definitely practice BSE as they will be aware of the importance of early detection of breast cancer in reducing mortality rate and worsening of the disease. This is similar to other study done among young adolescent girls in Abuja, Nigeria [15] and as well in concordance with the research on the influence of educational level on knowledge and practice of breast selfexamination among women in Sokoto [13]. Knowledge on BSE is insignificantly associated with the attitude of BSE which is likely due to the fact that respondents with adequate knowledge on BSE does not implies that the respondents will have a good behaviour towards BSE practice. This is similar to the outcome reported by the Authors of a research carried out on knowledge, attitude and practice of breast selfexamination among female undergraduate students in the University of Buea, who reported that $51.4 \%$ admitted that they were not afraid to detect breast cancer while $26.5 \%$ were afraid. $88 \%$ of the respondents approved that BSE was important and useful in the early detection of breast cancer [14].

\section{CONCLUSION}

This study revealed a larger proportion of respondents have heard about breast cancer and breast self-examination but with inadequate knowledge of the correct procedures of breast self-examination (BSE) thereby resulting into poor attitude \& practice of breast self-examination (BSE). This challenge therefore indicates an urgent need for continuous awareness and sensitization programs in the communities, as well as the review of high school subject curriculum to include breast self-examination (BSE) teaching and practice $\&$ general sexual and reproductive health programs.

There is need for the development of more efficient educational programs aiming at demonstrations of the correct procedures of breast self- examination (BSE) so as to enhance early detection of breast cancer and proffer prompt treatments to reduce the mortality rate of the breast cancer.

\section{ACKNOWLEDGEMENTS}

Our sincere appreciation goes to all participants that took part in this study, my supervisor and all staff members of the Department of Community Medicine, Ladoke Akintola University of Technology, Osogbo, Nigeria.

\section{FINANCIAL \& NON-FINANCIAL COMPETING INTEREST}

The authors declare no financial or non-financial competing interest.

\section{CONFLICT OF INTEREST}

Authors declare they have no conflict of interest. 


\section{REFERENCES}

[1] World Health Organization (WHO). Breast Cancer, prevention and control, $\quad$ Geneva. $2016 . \quad$ Available: http://www.who.oint/cancer/detection/breastcancer/en/index 1.html

[2] A. McGuire, J.A. Brown, C. Malone, R. McLaughlin, and M.J. Kerin (2015). 'Effects of age on the detection and management of breast cancer', Cancer, 7(2), pp. 908-29. doi: 10.3390/cancers7020815.

[3] American Cancer Society. Cancer Facts \& Figures 2015. Cancer Facts Fig 2015. 2015;1-9.

[4] C. Desantis, J. Ma, L. Bryan, and A. Jemal (2014). Breast cancer statistics, 2013. Cancer Journal of Clinicians, 64, pp. 52-62.

[5] J. Ferlay, H.R. Shin, F. Bray, D. Forman, C. Mathers, and D.M. Parkin (2014). Estimates of worldwide burden of cancer in 2008 . International Journal of Cancer, 127, pp. 2893-2917.

[6] G Ertem, and A. Kocer (2010). Breast self-examination among nurses and midwives in Odemis district in Turkey. Indian Journal of Cancer, 46 (3), pp. 208-213.

[7] O. Karayurt, D. Ozmen, and A.C. Cetinkaya (2008). Awareness of breast cancer risk factors and practice of breast self-examination among high school students in Turkey. BMC Public Health, 8, pp. 359.

[8] F.O. Kayode, T.M. Akande, and G.K. Osagbemi (2005). Knowledge, Attitude and Practice of Breast Self -Examination among Female Secondary School Teachers in Ilorin, Nigeria. European Journal of Scientific Research, 10 (3), pp. 42-47.

[9] U.M. Gwarzo, K. Sabitu, and S.H. Idris (2009). Knowledge and practice of breast self-examination among female undergraduate students of Ahmadu Bello University Zaria, northwestern Nigeria. Annals of African Medicine, 8(1), pp. 55-58.

[10] Chioma, and S.R.N. Asuzu (2007). Knowledge, attitude and practice of breast self-examination among female students of the University of Ibadan, Nigeria. Pakistan Journal of Social Sciences, 4 (3), pp. 400-402.

[11] J.O. Faronbi, and J. Abolade (2012). Breast self-examination practices among female secondary school teachers in a rural community in Oyo State, Nigeria. Open Journal of Nursing, 2(2), pp. 111-115.

[12] A.A. Yakubu, M.A. Gadanya, and A.A. Sheshe (2014). Knowledge, attitude, and practice of breast self-examination among female nurses in Aminu Kano teaching hospital, Kano, Nigeria. Nigerian Journal of Basic and Clinical Sciences, 11, pp. 85-88.

[13] A.M. Sani, F. Naab, and L. Aziato (2016). Influence of educational level on knowledge and practice of breast self-examination among women in Sokoto, Nigeria. Journal of Basic and Clinical Reproductive Sciences, 5, pp.100- 106.

[14] F.P. Nde, J.C.N. Assob, T.E. Kwenti, A.L. Njunda, and T.R.G. Tainenbe (2015). Knowledge, attitude and practice of breast selfexamination among female undergraduate students in the University of Buea. BMC Research Notes, 8, pp.43.

[15] A.R. Isara, and C.I. Ojedokun (2011). Knowledge of breast cancer and practice of breast self-examination among female senior secondary school students in Abuja, Nigeria. Journal of Preventive Medicine and Hygiene, 52, pp. 186-190.

[16] B.H. Abou. Breast Self-Examination (BSE) (2016). Knowledge and Practice among Female Faculty of Physical Education in Assuit, South Egypt. Journal of Medicine, Physiology and Biophysics, 25, pp. 1-8.

[17] M. Onyeka, D. Hakeem, and I. Adu (2015). An appraisal of the knowledge, attitude and practice of breast self-examination among university female nursing undergraduates and the factors that affect their practice of BSE. African Journal of Nursing and Midwifery, 2 (7), pp.565-570.

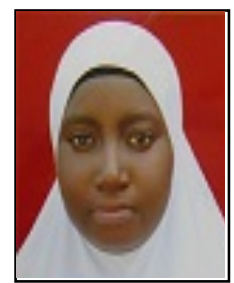

Ibiwumi Usman is an efficient public health professional whose interest is in the field of public health with strong passion for adolescents and young persons' reproductive health, sexually transmitted infections and teenage pregnancy in Nigeria. She has several publications in reputable local \& international journals. 